\title{
Principals' Attitudes, Knowledge, and Beliefs Regarding Active Learning Methodologies in Spain
}

\author{
Lidon Moliner ${ }^{1, *}$, Francisco Alegre ${ }^{2}$ \\ ${ }^{1}$ Department of Pedagogy, Jaume I University, Spain \\ ${ }^{2}$ Department of Didactics of Mathematics, Valladolid University, Spain
}

Received July 14, 2020; Revised August 31, 2020; Accepted September 17, 2020

\begin{abstract}
Cite This Paper in the following Citation Styles
(a): [1] Lidon Moliner, Francisco Alegre, "Principals' Attitudes, Knowledge, and Beliefs Regarding Active Learning Methodologies in Spain," Universal Journal of Educational Research, Vol. 8, No. 11, pp. 5322 - 5334, 2020. DOI: 10.13189/ujer.2020.081134.
\end{abstract}

(b): Lidon Moliner, Francisco Alegre (2020). Principals' Attitudes, Knowledge, and Beliefs Regarding Active Learning Methodologies in Spain. Universal Journal of Educational Research, 8(11), 5322 - 5334. DOI: 10.13189/ujer.2020.081134.

Copyright $\odot 2020$ by authors, all rights reserved. Authors agree that this article remains permanently open access under the terms of the Creative Commons Attribution License 4.0 International License

\begin{abstract}
The attitudes, beliefs, and knowledge of primary and secondary school principals in Spain regarding active learning methodologies were investigated. To this purpose, a questionnaire, which may be used by an international audience, was designed to measure these factors. Validation and reliability assessments and exploratory and confirmatory factor analysis were carried out. Study participants included 24 experts from European universities and 408 principals from Spain. Results were analyzed according to the principals' years of experience, sex, region, school ownership (public vs. private), and school educational stage (primary vs. secondary). Study findings indicate that principals in Spain possess significant knowledge and positive attitudes and beliefs regarding active learning methodologies. Primary school principals, as well as principals with between four and eight years of experience, showed stronger beliefs and greater knowledge than their peers. The educational stage of the school and years of experience of the principal combined acted as moderators for beliefs and knowledge. A strong correlation was found between attitudes about and knowledge of active learning methodologies. It can be concluded that, although attitudes are strongly related to knowledge, beliefs are independent of both, and, as in other areas of the managerial function, they are rarely influenced by other factors. These factors do not depend on the sex of the principal who exercises the managerial function or on the region in which he/she works. However, the educational stage of students in the institution, the
\end{abstract}

ownership of the school, and the years of experience may significantly influence principals' knowledge and attitudes.

Keywords Principals, Beliefs, Attitudes, Knowledge, Active Learning Methodologies

\section{Introduction}

Principals' influence on the methodologies and practices carried out by teachers in the classroom has been widely documented. Indeed, authors such as Sebastian, Camburn, and Spillane [1] and Firestone and Donaldson [2] indicated that principals can have a great influence on the work of their colleagues. This influence can be positive or negative, and most often, it ends up directly or indirectly affecting the students [3]. Thus, in addition to the significant influence principals have through their own management, teaching, and leadership roles, their impact further extends to the teaching methodologies used by the faculty on staff. In this way, factors as important as the inclusion of all students in the institution and the use of participative methodologies by teachers are largely contingent on the influence of the school's principal $[4,5]$.

This work aims to investigate the attitudes, knowledge, and beliefs of principals in Spain regarding active learning methodologies. Active learning has been described by 
various authors as one of the major foundations on which the education of the future should be built, given its strong inclusive character and its focus on giving students a lead role in their own learning [6]. However, studies in this field, as indicated by Grummel [7], are scarce. At the international level, the absence of validated questionnaires that serve to investigate aspects of active learning methodologies is notorious. The importance of principals regarding the implementation of this type of methodology in the classroom and the lack of studies and resources in the field justify this research, both nationally, in terms of the findings, and internationally, for the provision of an evaluation tool.

\section{Theoretical Framework}

In this section, the various theories on which this research is based are presented. First, principals' influence on their faculty's selection of teaching methods is discussed. Second, the importance of investigating principals' attitudes, beliefs, and knowledge is reviewed. Finally, the importance of active learning methodologies is explained.

\subsection{Principals' Attitudes, Beliefs, and Knowledge}

As noted, various factors affect the influence principals exert over organizational, cultural, and methodological aspects of their school operations; three factors are repeated most frequently: attitudes, beliefs or opinions, and knowledge or training.

To examine principals' beliefs, their perceptions or opinions regarding pedagogical issues were recently investigated by, for example, Cohen-Azaria and Zamir [8] Mady and Masson [9], DeMatthews, Kotok, and Serafini [10], Brauckmann, Pashiardis and Ärlestig [11], and Larsson and Rönnlund [12]. These studies verified that the belief factor can play a significant role in a principal's influence on various school matters and, therefore, should be considered an important factor for examination.

In addition, principals' attitudes have also been studied frequently over the past several decades. However, the attitude factor rarely stands alone; it is usually accompanied by other factors, such as beliefs, perceptions, opinions, or knowledge. Thus, based on related studies in the field, such as those by Liljenberg and Andersson [13], Touloupis and Athanasiades [14], Nehez and Blossing [15], and Mælan, Tjomsland, Baklien and Thurston [16], principals' attitudes should also be investigated.

Like beliefs and attitudes, principals' knowledge is one of the most often examined factors within the managerial function of the principal's role. This is the main factor that is investigated in the works of Holmes and Young [17], Smith-Millman and Flaspohler [18], Reid [19], and Fitzgerald and Radford [20].
Considering these three factors are the most commonly examined within various investigations of the managerial function of the school principal, they were selected for analysis within the present work. As Reber [21] and Reid [22] state, it is important to link knowledge with other psychological factors in educational and psychological research so that stronger conclusions may be obtained. Hence, all these factors were analyzed and the possible links among them were examined.

\subsection{Active Learning Methodologies}

Active learning methodologies can be defined as instructional methods in which students are given a leading role in their learning $[23,24]$. In these learning methodologies, students are actively involved in their learning besides passively listening. Since the early 2000 s, several authors have emphasized the effectiveness of these methodologies, which constitute an alternative to traditional teaching, in which the teacher is the protagonist of learning. Following the active learning methodology, students themselves become responsible for their own learning. The effectiveness of active learning across educational stages and subjects and within diverse environments has been verified by various researchers, such as Jeong, González-Gómez, Gallego-Picó, Bravo [25], Shekhar, Prince, Finelli, Demonbrun, and Waters [26], and Reid [27]. According to these authors, students often feel very comfortable in the classroom when active learning methodologies are applied, and they have highly positive perceptions about these practices. Although active learning methodologies take on many forms and encompass many types of active and participatory methodologies, covering all methodologies in a research study is practically impossible. Therefore, this work focuses on six active learning methods that are considered most common, are most widely known, and have been studied most often thus far. As a result, however, some of the most promising methods, such as the inverted class or flipped classroom are not covered in this work [28]. The six common active learning methodologies currently used in classrooms that will be studied in this work are cooperative learning, peer tutoring, service learning, interactive groups, work for projects, and workshops and corners [29-32].

\subsection{Principals' Influence on the Active Learning Methodologies Used in Schools}

The influence principals have on their schools has been the subject of many studies for over three decades, following a considerable increase in the number of studies in this field in the late 1980s and early 1990s. Thus, several prominent publications in the field have already documented the influential role of the principal in the proper functioning of their schools. For example, 
Leithwood and Jantzi [33] indicated that, by means of active learning methodologies, factors such as classroom climate, student work time in the classroom, and educational values themselves were strongly affected by the figure of the principal. The first relevant research in this field dates back to the 1960s with the study carried out by Chesler, Schmuck, and Lippitt [34], in which the authors concluded that the influence of principals, expressed through both their actions and opinions, is vital during pedagogical innovation processes carried out in a school. This pioneering research study would be followed by others, such as studies by Ogawa and Weaver Hart [35] and by McEvoy [36], which reinforced the thesis proposed by Mahan [37]. Conley [38] made special reference to the role of maximum authority at the school level, understanding that the final decision in many aspects of teaching and learning, both methodological and non-methodological, rests with the principal. The findings of these pioneering investigations were endorsed over the past several decades. Recently, studies such as those by Tingle, Corrales, and Peters [39] and by Cáceres [40] investigated the factors behind the influence of principals in implementing learning innovations. These investigations pointed to motivational, social, and environmental factors (students, infrastructure, etc.) as the main influences on principals' beliefs and attitudes regarding methodological innovation. Previous research by Quinn [41], Mitchell and Sackney [42] or Mullen and Hutinger [43] states that principals' role is key to teachers' instructional practice. In this sense, principals are the ones that generate the organizational conditions for the teachers to implement these active learning methodologies. Furthermore, authors such as Hallinger, Liu, and Piyama [44] or Romanowski, Sadiq, Abu-Tineh, Ndoye, and Aql [45] indicate that factor such as principals' beliefs or their knowledge may influence the use of active methodologies in their schools and that more research is needed in the field addressing principals' knowledge and beliefs towards active learning. Hence, given the proven potentiality of active learning methodologies and the importance of principals' role in their implementation at their schools, principals' attitudes, beliefs and knowledge regarding active learning methodologies were analyzed in this research.

\section{Objectives and Hypothesis}

\subsection{Objectives}

Following the theoretical basis indicated in the preceding sections, the following objectives were established for this research work.

1. To prepare and validate a questionnaire that measures principals' knowledge, beliefs, and attitudes regarding active learning methodologies that can be used by an international audience.

2. To determine the knowledge, beliefs, and attitudes of principals in Spain regarding active learning methodologies.

3. To identify possible differences in the knowledge, beliefs, and attitudes of principals in Spain according to school ownership (public vs. private), school educational stage (primary vs. secondary), region (autonomous community), sex (male or female), and years of experience as principal (less than four years, between four and eight years, more than eight years).

\subsection{Hypothesis}

Based on these objectives, the following research hypotheses were defined:

- Hypothesis 1: Principals' knowledge regarding active learning methodologies is low.

- Hypothesis 2: Principals have negative beliefs regarding active learning methodologies.

- Hypothesis 3: Principals' attitudes regarding active learning methodologies are negative.

- Hypothesis 4: There are no significant differences in principals' attitudes, beliefs, and knowledge based on the school ownership (public vs. private) where the principal practices.

- Hypothesis 5: There are no significant differences in principals' attitudes, beliefs, and knowledge based on the educational stage (primary vs. secondary) of the school where the principal practices.

- Hypothesis 6: There are no significant differences in principals' attitudes, beliefs, and knowledge based on the region in which the principal belongs (autonomous community).

- Hypothesis 7: There are no significant differences in principals' attitudes, beliefs, and knowledge based on the principals' sex.

- Hypothesis 8: There are no significant differences in principals' attitudes, beliefs, and knowledge based on the principals' years of experience as a principal (less than four years, between four and eight years, more than eight years).

- Hypothesis 9: There are strong correlations among the factors of attitudes, beliefs, and knowledge.

- Hypothesis 10: Principals' sex, school ownership, years of experience, and the educational stage of the principal's school combined do not act as moderators of the results for any of the factors.

\section{Materials and Methods}

\subsection{Participants}

Participants in this study can be divided into two groups: 
(1) experts who collaborated in the validation of the questionnaire, and (2) principals who responded to the questionnaire.

First, the collaboration of experts who could validate the questionnaire was required. Experts were selected with consideration of their curriculum and their experience in the field, most being full-time university professors [46]. With the aim of developing a questionnaire that could be used by an international audience, 93 experts from different European universities were contacted. A total of 24 collaborated, their responses validating the questionnaire.

Second, in order to carry out the subsequent reliability analysis, factor analysis, and statistical descriptive and inferential calculations, principals' collaboration was required. According to the State Register of Non-University Teaching Centres provided by the Ministry of Education, in 2018 there were 21,492 primary and secondary schools in Spain. Of these, approximately two thirds were primary schools (grades 1 to 6 , with 7- to 12-year-old students) and one third were secondary schools (grades 7 to 12 , with 13- to 18-year-old students). The collaboration of 1,000 principals nationwide was requested through a simple random sampling, so all principals nationwide had the same probability of being selected [47]. Ultimately, 408 principals participated in the study.

\subsection{Sample Representativeness}

Considering the population of school principals in Spain, various authors would consider this population (408 participating principals), as long as the total number of individuals in the population was greater than 10,000 [48]. These authors suggested that to obtain a representative sample for this type of population, slightly less than 400 responses $(5 \%$ error margin, $95 \%$ confidence interval) should be obtained. Therefore, having obtained 408 responses, the sample of principals surveyed in this work can be considered representative of the population.

\subsection{Sample Power}

Study Size 3.0 software developed by Creostat was used to determine sample power. The sample power of .98 was determined for this study given the sample size of 408 subjects, a significance level of .05 and a correlation coefficient difference of .2 between the null hypothesis (not significant correlation) and the alternative hypothesis (significant correlation).

\subsection{Instruments and Tools}

The instrument used in this investigation was the questionnaire that was developed and validated and that served as a tool to perform the different measurements. Expert responses were collected through a Google Forms tool. The questionnaire was distributed to principals through ordinary postal mail; a self-addressed, stamped envelope was included with the questionnaire in the mailing for the principals to use to return their completed questionnaire. In both cases, research ethics provided by the Spanish Ministry of Research were followed and the anonymity of both, experts and principals was guaranteed during the whole process. The different reliability analyses and the exploratory factor analysis (EFA) of the questionnaire were performed using SPSS software version 24 , which was also used to obtain the descriptive and inferential results. The confirmatory factor analysis (CFA) was conducted using EQS software version 6.2. Process software version 3.3 for SPSS was used for the moderation analysis.

\subsection{Procedure}

First, a review of the literature on existing questionnaires related to principals' beliefs, attitudes, and knowledge regarding various topics was conducted. As indicated by Onwuegbuzie, Bustamante, and Nelson [49], extensive knowledge in the field of research is necessary before formulating questionnaire items. Second, and after consulting the relevant bibliographies an initial design for the questionnaire was developed following the recommendations of Krosnick and Fabrigar [50], who suggested the need to define a specific initial questionnaire structure (the three factors of attitudes, beliefs, and knowledge). Based on this initial design, the authors of this work drafted the questionnaire items. The Delphi method was used to support the questionnaire's validity and to reach a consensus when deciding which questions to include [51]. The Total Design Method by Dillman [52], which offers guidelines on how to write questionnaire items to ensure a greater number of responses, was also followed. Finally, a five-point Likert scale was defined for the questionnaire. Hence, the higher a principal's score, the stronger or greater the attitudes, beliefs, and knowledge that principal possessed.

After its initial design, the questionnaire was submitted for expert judgment. Expert judgment provides an evaluation of whether the elements are appropriate and whether they appropriately relate to the defined concepts [53]. E-mail was used to distribute the survey and receive responses for expert judgment, as the use of other means, that is, regular mail or telephone, would not guarantee greater reliability of the results [54]. Plus, e-mail was the least expensive and fastest method by which to obtain responses. Experts' contributions were completely anonymous, and the Lawshe method [55] was used. Hence, experts graded the suitability of each questionnaire item using the following scale: (1) item not useful, (2) item useful but not essential, and (3) item essential. All 
responses were recorded using the Google Forms tool. The experts' answers were analyzed considering changes in current theories on the values contributed by Lawshe as critical [56]. Subsequently, the degree of agreement between experts was analyzed. As indicated by Banerjee, Capozzoli, McSweeney, and Sinha [57], it is necessary to analyze the degree of agreement among experts to verify whether, in fact, the questionnaire is suitable for measurements. The intraclass correlation coefficient was the statistic selected to measure the degree of agreement among the experts, since it is the most appropriate to analyze ordinal responses [58].

Once the validation process was completed, the reliability of the questionnaire was analyzed. For this, a global statistical analysis and an individual item analysis for each item were carried out using Cronbach's alpha; once these analyses were completed, the Spearman-Brown and Guttmann coefficients were used as complementary tests [59].

After analyzing the reliability of the questionnaire, an EFA was performed [60]. Prior to its completion, the feasibility of carrying out an EFA was verified using the Kaiser-Meyer-Olkin and Bartlett sphericity tests. After ensuring the feasibility of performing a factor analysis, the EFA was performed using the Kaiser method with a varimax rotation [61], analyzing the Eigenvalues that were obtained and the percentage of variance explained by all values collectively.

Based on these responses, a CFA was performed [62]. The Bentler comparative adjustment index (CFI) and the Joreskog-Sorbom adjustment index (GFI) were used as the goodness of adjustment indices, while the Chi-square divided by degrees of freedom $\left(\chi^{2} / \mathrm{df}\right)$ and the square root of the residual mean (RMR) were used as indices of the badness of adjustment. To achieve an adequate structure, according to $\mathrm{Hu}$ and Bentler [63], the CFI and GFI values should be .90 or above (the more, the better), the RMR should be 0.06 or lower, and the $\chi^{2}$ / df should be below 4 (the lower, the better).

Finally, a statistical analysis was performed. Global results were obtained, and comparisons were carried out between the variables noted. For those variables with only two options (school ownership, school educational stage, and principal's sex), the Student's t-test [64] was used as a statistic for the comparison of means $(\mathrm{p}<.05)$. For those variables for which there were more than two options (region and years of experience as principal), ANOVAs were used for the comparison of means [65], and when statistically significant differences were reported, the Scheffe test was used [66]. The possible correlation between the three factors was analyzed using Pearson's correlation coefficient [67]. In response to the recommendations of different education researchers, an $r$ value of .5 was taken as the minimum value to consider that the correlation between factors was at least moderate [68]. A test for moderator effects was performed for the three factors, combining the variables of school educational stage, years of experience, school ownership, and sex in pairs. Regression analyses were run for this purpose, following the indications provided by Hayes [69].

\section{Results}

The results for each phase of the study procedure are presented in the following sections.

\subsection{Creation and Validation of the Questionnaire}

Following the procedure as explained, an initial version of the questionnaire was prepared and submitted for expert judgment. This initial version, which consisted of 27 items equally distributed among the three factors of attitudes, beliefs, and knowledge, was subject to validation by experts. The content validity ratio (CVR) defined by Lawshe indicated that five of the initial 27 items should be deleted, in accordance with the expert judgment feedback, due to their low scores $(\mathrm{CVR}<.42)$, reducing the questionnaire to 22 items.

An intraclass correlation coefficient of .68 was reported for the degree of agreement between experts. The version of the questionnaire that remained after the validation process by experts, which can be found in the appendix section, was the version that was used for the ongoing research.

\subsection{Questionnaire Reliability Analysis}

A global Cronbach's alpha value of .91 was obtained for the questionnaire. This value did not increase when items were deleted; hence, all 22 items were kept. Spearman-Brown and Guttmann coefficients of .59 and .58 were reported.

\subsection{Exploratory Factor Analysis}

The suitability of performing an EFA was ensured, as a Kaiser-Meyer-Olkin value of .78 and Bartlett's sphericity test value of 807.72 were obtained. The EFA revealed the existence of three Eigenvalues, that is, three factors that together explained $76.35 \%$ of the variance.

\subsection{Confirmatory Factor Analysis}

The CFA was carried out with respect to the initially designed three-factor structure (attitudes, beliefs, and knowledge), including each item in its respective factor. The following values were obtained: $\mathrm{CFI}=.93$, GFI $=.94$, $\chi 2 / \mathrm{df}=2.01$, and $\mathrm{RMR}=0.04$.

\subsection{Statistical Analysis}

The highest average score was reported for the attitudes 
factor (4.30), followed by the knowledge factor (3.94) and the belief factor (3.53) with regard to active learning methodologies.

The Student's t-test by sex did not show statistically significant differences in knowledge $(\mathrm{t}=0.72, \mathrm{p}=.47)$, in attitudes $(\mathrm{t}=0.31, \mathrm{p}=.76)$, nor in beliefs $(\mathrm{t}=1.23, \mathrm{p}=.22)$ regarding active learning methodologies. However, in the analysis by school ownership, statistically significant differences were reported for all three factors. While private school principals showed significantly greater knowledge than public school principals $(\mathrm{t}=2.10, \mathrm{p}=.04)$ related to active learning methodologies, public school principals showed significantly more positive attitudes $(\mathrm{t}$ $=2.07, \mathrm{p}=.04)$ and beliefs $(\mathrm{t}=3.24, \mathrm{p}<.01)$ related to these methodologies than their peers.

The analysis by the educational stage of the principals' schools revealed that primary school principals had significantly greater knowledge and more positive attitudes about active learning methodologies than secondary school principals $(\mathrm{t}=5.34, \mathrm{p}<.01 ; \mathrm{t}=4.71, \mathrm{p}$ $<$.01) related to active learning methodologies. However, no statistically significant differences were detected for the beliefs factor in this case $(t=0.78, p=.43)$.

The analysis by years of experience revealed statistically significant differences for the knowledge $(\mathrm{F}=$ $3.72, \mathrm{p}=.03)$ and attitudes $(\mathrm{F}=3.28, \mathrm{p}=.04)$ factors regarding active learning methodologies. However, no statistically significant differences were detected for the beliefs factor in this analysis $(\mathrm{F}=0.13, \mathrm{p}=.88)$. Scheffe's tests showed that principals who had 4 to 8 years of experience had significantly greater knowledge and more positive attitudes about active learning methodologies than their less and more experienced peers.

The analysis by region did not report statistically significant differences for any of the factors, including knowledge $(\mathrm{F}=0.66, \mathrm{p}=.85)$, attitudes $(\mathrm{F}=0.67, \mathrm{p}=.83)$, and beliefs $(\mathrm{F}=0.62, \mathrm{p}=.88)$.

The correlation analysis between the three factors showed a moderate correlation between the factors of attitudes and knowledge $(r=.55)$. However, no significant correlations were detected between the factors of knowledge and beliefs $(\mathrm{r}=.31)$ or between the factors of attitudes and beliefs $(\mathrm{r}=.32)$.

The moderators test showed that only the educational stage of the school (E) and years of experience (Y) acted as moderators for beliefs $(\mathrm{B}=-.33, \mathrm{p}=.02)$ and knowledge $(\mathrm{B}=-.26, \mathrm{p}=.03)$. No other combination with school ownership (O) or sex (S) showed significant moderation.

\subsection{Confirmation and Rejection of Hypotheses}

- Hypothesis 1 (principals have low knowledge regarding active learning methodologies) is rejected, since a score of 3.94 out of 5 possible points shows the principals possess a high degree of knowledge on the subject.
- Hypothesis 2 (principals have negative beliefs regarding active learning methodologies) is also rejected, as a result of the score of 3.50 out of 5 possible points, which, although improvable, cannot be considered low.

Hypothesis 3 (principals have negative attitudes regarding active methodologies) is also rejected, as this was the factor with the highest score (4.3 out of 5 possible points).

- $\quad$ Hypothesis 4 (there are no significant differences in principals' attitudes, beliefs, and knowledge based on school ownership) is rejected, since statistically significant differences were detected for the three factors based on school ownership.

- Hypothesis 5 (there are no significant differences in principals' attitudes, beliefs, and knowledge based on the school educational stage) is also rejected, since two of the factors (knowledge and attitudes) showed statistically significant differences based on this variable.

- Hypothesis 6 (there are no significant differences in principals' attitudes, beliefs, and knowledge based on their region) is confirmed, since no statistically significant differences were reported for any of the three factors based on region.

- Hypothesis 7 (there are no significant differences in principals' attitudes, beliefs, and knowledge based on the principal's sex) is confirmed, since no statistically significant differences were detected for any of the three factors based on the sex of the principals.

- Hypothesis 8 (there are no significant differences in principals' attitudes, beliefs, and knowledge regarding their years of experience) is rejected, since statistically significant differences were reported for two of the factors (knowledge and attitudes) based on the principals' years of experience.

- Hypothesis 9 (there are strong correlations among the factors of attitudes, beliefs, and knowledge) is rejected, since the only correlation indicated was between the factors of attitudes and knowledge.

- Hypothesis 10 (principals' sex, school ownership, years of experience, and school educational stage combined do not act as moderators of the results for any of the factors) is rejected, as years of experience and educational stage combined acted as moderators for beliefs and knowledge.

\section{Discussion}

The descriptive results obtained from this study are consistent with previous research in the field. Studies by Bolívar and Moreno [70], Bolívar-Botía and Bolívar-Ruano [71], and Ritacco and Bolivar [72] previously demonstrated that principals in Spain usually 
have significant knowledge and positive attitudes and beliefs regarding innovation in teaching. Hence, it is not surprising that this study's findings indicate that principals in Spain have positive attitudes and beliefs and substantial knowledge about active learning methodologies. Unlike in other nations, in Spain, principals frequently teach four to five hours a week in addition to performing all the organizational and managerial tasks that their position requires [73]. Thus, it is understandable that they are up-to-date with new trends in teaching and learning.

The fact that a strong correlation between attitudes and knowledge was reported is consistent with prior research conducted on educational management. Although not specifically regarding active learning methodologies, previous studies by Berger, Reupert, and Hasking [74], Swanson and Gettinger [75], Kuyini, Desai, and Sharma [76], Henriksen and Aas [77], and Touloupis and Athanasiades [78] also indicated that principals' attitudes and knowledge are strongly related, according to these studies, in aspects such as educational inclusion or attention to diversity. As Barnett and Monda-Amaya [79], Watkins, Anthony and Beard [80], and Nadav, Benoliel, Shaked and Schechter [81] pointed out, this phenomenon may be because in the field of education, increased knowledge in a field of study usually leads to an increase in a positive attitude towards that subject. However, this does not apply to beliefs. As Araújo, Macedo, Santos and Doroftei [82], Turk and Wolfe [83], Hayes and Irby [84], and Nordholm, Arnqvist and Nihlfors [85] indicated, a belief, specifically with regard to principals, seems to be a very unique and particular factor inherent in each person, which is not often affected by other factors. This would explain the lack of correlation between beliefs and the factors of knowledge and attitudes.

Regarding the inferential analyses, the fact that primary school principals had significantly greater knowledge and more positive attitudes than secondary school principals about active learning methodologies had already been reported in other studies around the world [86-89]. The cause of this phenomenon, as pointed out by Thody, Papanaoum, Johansson, and Pashiardis [90] and Lazenby, McCulla and Marks [91], probably lies in the fact that training for primary and secondary school principals is very different. In Spain, primary school principals receive three to four years of teacher training, while secondary school principals only receive from a few months up to a year of teacher training. These differences in the amount of teacher training affect principals' knowledge of active learning methodologies, and, as there is a direct correlation between knowledge and attitudes, their attitudes are also affected.

The strong similarities between the sexes on the three factors indicated in the results in this work do not match findings from previous research in the field. For example, studies by Coronel, Moreno and Carrasco [92], Sebastian and Moon [93] and Lorentzen [94] demonstrated that female principals tend to have better attitudes and stronger beliefs regarding inclusive educational issues and cooperative methodologies than their male counterparts. Authors such as Vestal and Torres [95], Randall and West [96], and Hauseman [97] pointed out that, in this sense, the special sensitivity of women principals towards the well-being and integration of students in the educational institution could be a factor that explains these differences between male and female principals. In this regard, the results of this work differ from what the literature more often reflects in this field of study.

Regarding the differences found between public and private school principals, previous studies, such as those of Mancebón and Muñiz [98], Cordero, Prior, and Simancas [99], and Goddard, Bailes and Kim [100] already indicated that managerial differences between a private and a public school are important. In their study, Dronkers and Avram [101] indicated that the differences between the form of access to the job, the training requirements at the managerial level, and the socioeconomic level of the families and students of each school significantly influence principals' attitudes and beliefs. Hence, the important differences detected in this study according to the ownership of the school can be explained from this perspective.

The few differences found by region are consistent with previous studies by Ferrera, Cebada, Chaparro, and González [102] and Crespo-Cebada, Pedraja-Chaparro, and Santín [103]. These authors pointed out that, although several national and international reports indicated important differences at the academic level in students, principals' competencies and visions are very similar throughout the nation, regardless of the region in which they are located. Therefore, it is understandable that no statistically significant differences were detected for this variable.

Regarding the results obtained by years of experience as a principal, the important differences detected in attitudes can be justified according to various prior studies. Authors such as Shaked and Schechter [104], Reid [105] and Aas, Vennebo and Halvorsen [106] pointed to the period between four and eight years of experience as a principal as probably the best time for the management exercise at the attitudinal level. According to these authors, principals have already overcome the inexperience of the first years in their managerial role, and the effects of burnout or exhaustion have not yet taken place for most of them [107]. Although it is difficult to explain why principals with between four and eight years have more knowledge than their colleagues with more than eight years of experience, the differences can be justified from the perspective of the strong correlation between attitudes and knowledge, as noted previously.

Finally, when considering the results obtained in this work, several limitations must be considered. From a statistical perspective, although the indicated values of 
reliability, CFI, GFI, and RMR are suitable for various authors [108] they may be insufficient for other authors who demand more robust values in this regard. For instance, authors such as Li [109] noted that the CFI and GFI values should be above .95 to ensure the adequacy of the obtained factorial structure. Besides, the degree of agreement between experts may also be considered as improvable by some authors which may have compromised the international validity of the questionnaire [110]. Hence, future studies in the field that address its reliability across different countries and cultures will be necessary to ensure its suitability for an international audience. In the same way, although the sample obtained for the present work may be representative as described, a smaller margin of error would have resulted in a much larger sample and, therefore, in a higher participation that would have helped to further endorse the results obtained [111]. Failure to obtain a larger sample in this work is justified from the economic and temporary limitations.

\section{Conclusions}

Multiple conclusions can be obtained from this work. First, it can be concluded that attitudes, beliefs, and knowledge of principals in Spain regarding active learning methodologies are high. Although attitudes are strongly related to knowledge, beliefs are independent of both, and, as in other areas of the managerial function, they are rarely influenced by other factors. In the same way, it can be concluded that these attitudes, beliefs, and knowledge do not depend on the sex of the principal who exercises the managerial function or on the region in which he/she works. However, the educational stage of students in the institution, the ownership of the school, and the principals' years of experience can have an important influence on knowledge and attitudes. Thus, primary school principals and principals with between four to eight years of experience will have greater knowledge and more positive attitudes regarding active learning methodologies than their counterparts in secondary schools and with different years of experience, respectively. The differences in the teacher training of the principals and the suitability of four to eight years of experience, falling between the inexperienced phase and the burnout or exhaustion phase of a principal's career, are factors that explain the highest scores in these cases. Differences between public and private educational institutions are important, as principals in the public system have more positive beliefs and attitudes, while principals in the private system have greater knowledge.

\section{Acknowledgments}

This work was supported by the Universitat Jaume I under the project "Análisis de las prácticas de aula y su impacto en variables socieducativas del alumnado en espacios musicales. Un estudio desde una perspectiva intercultural inclusiva". UJI-B2019-16".

\section{Appendix}

\section{PRINCIPALS' QUESTIONNAIRE REGARDING ACTIVE LEARNING METHODOLOGIES}

Sex: Female Male

Years of experience as a principal:

Less than 4 years 4 to 8 years More than 8 years

\section{FACTOR 1: KNOWLEDGE}

\section{ABSOLUTELY NOT 5. ABSOLUTELY}

1 - I know what "cooperative learning" consists of.

2 - I know what "peer tutoring" consists of.

3 - I know what "service learning" consists of.

4 - I know what "interactive groups" consists of.

5 - I know what "project-based learning" consists of.

6 - I know what "workshops and corners" consists of.

7 - I know the benefits and potentialities for students when interacting and helping one another.

8 - I have received training (talks, courses, workshops, seminars, etc.) on how to organise and plan with students to work in pairs.

9 - I have received training (talks, courses, workshops, seminars, etc.) on how to organise and plan with students to work in groups. 


\section{FACTOR 2: ATTITUDES}

\section{NEVER \\ 5. ALWAYS}

10 - As a principal, I encourage teachers to use active learning methodologies.

11 - As a principal, I foster the use of different didactic materials apart from the textbook.

12 - As a principal, I facilitate adaptations in the schedule so that teaching tasks can be achieved.

13 - As a principal, I foster the use of all educational spaces available in my institution.

14 - As a principal, I foster the participation of students' families in the learning processes at my institution.

15- As a principal, I look for the collaboration of the community, associations, and other institutions in the learning processes at my institution.

\section{FACTOR 3: BELIEFS}

\section{COMPLETELY DISAGREE \\ 5. ABSOLUTELY AGREE}

16 - Working in pairs helps both the most competent and the least competent students.

17 - Students can work on any subject in groups and achieve high academic results.

18 - Cooperative learning is not associated with more discipline problems than individual learning.

19 - It is as important to work on curricular content as it is to work on social and interpersonal relationships.

20 - It is important that students' families participate in classroom activities.

21 - It is important that the community, associations, and other institutions participate in classroom activities.

22 - Students must be paired or placed in groups with consideration given to their motivations and abilities.

\section{REFERENCES}

[1] Sebastian, J., Camburn, E. M., \& Spillane, J. P. (2018). Portraits of principal practice: Time allocation and school principal work. Educational Administration Quarterly, 54(1), 47-84. https://doi.org/10.1177/0013161X17720978

[2] Firestone, W. A., \& Donaldson, M. L. (2019). Teacher evaluation as data use: what recent research suggests. Educational Assessment, Evaluation and Accountability, 1-26. Epub ahead of print. https://doi.org/10.1007/s11092-0 19-09300-z

[3] Dhuey, E., \& Smith, J. (2018). How school principals influence student learning. Empirical Economics, 54(2), 851-882. https://doi.org/10.1007/s00181-017-1259-9

[4] Hallinger, P., \& Hosseingholizadeh, R. (2019). Exploring instructional leadership in Iran: A mixed methods study of high-and low-performing principals. Educational Management Administration \& Leadership. Epub ahead. https://doi.org/10.1177/1741143219836684

[5] Yazicioglu, T. (2020). Determining the Views of School Principals and Guidance Teachers on Inclusive Practices at Anatolian High-Schools. Journal of Education and Learning, 9(1), 87-98.

[6] Al-Shammari, Z. N., Faulkner, P. E., \& Forlin, C. (2019). Theories-based Inclusive Education Practices. Education Quarterly Reviews, 2(2), 408-414. https://doi.org/10.31014/ aior.1993.02.02.73

[7] Grummell, B. (2016). Opportunities and Obstacles: how school leaders view development education in Irish post-primary schools. Policy and Practice-A Development

[8] Cohen-Azaria, Y., \& Zamir, S. (2018). School principals' perceptions and requirements of school evaluators. Quality Assurance in Education, 26(4), 489-501. https://doi.org/10.1108/QAE-01-2018-0006

[9] Mady, C., \& Masson, M. (2018). Principals' beliefs about language learning and inclusion of English language learners in Canadian elementary French immersion programs. Canadian Journal of Applied Linguistics/Revue canadienne de linguistique appliquée, 21(1), 71-93. https://doi.org/10.7 202/1050811ar

[10] DeMatthews, D. E., Kotok, S., \& Serafini, A. (2019). Leadership Preparation for Special Education and Inclusive Schools: Beliefs and Recommendations From Successful Principals. Journal of Research on Leadership Education. Epub ahead of print. https://doi.org/10.1177/194277511983 8308

[11] Brauckmann, S., Pashiardis, P., \& Ärlestig, H. (2020). Bringing context and educational leadership together: fostering the professional development of school principals. Professional Development in Education, 1-12. https://doi.or $\mathrm{g} / 10.1080 / 19415257.2020 .1747105$

[12] Larsson, A., \& Rönnlund, M. (2020). The spatial practice of the schoolyard. A comparison between Swedish and French teachers' and principals' perceptions of educational outdoor spaces. Journal of Adventure Education and Outdoor Learning, 1-12. https://doi.org/10.1080/14729679.2020.175 5704

[13] Liljenberg, M., \& Andersson, K. (2018). Novice principals' attitudes toward support in their leadership. International Journal of Leadership in Education, 1-18.Epub ahead of print. https://doi.org/10.1080/13603124.2018.1543807

[14] Touloupis, T., \& Athanasiades, C. (2018). Principals' 
attitudes towards risky internet use of primary school students: The role of occupational factors. Education and Information Technologies, 23(1), 497-516. https://doi.org/10.1007/s10639-017-9614-

[15] Nehez, J., \& Blossing, U. (2020). Practices in different school cultures and principals' improvement work. International Journal of Leadership in Education, 1-21. https://doi.org/10.1080/13603124.2020.1759828

[16] Mælan, E. N., Tjomsland, H. E., Baklien, B., \& Thurston, M. (2020). Helping teachers support pupils with mental health problems through inter-professional collaboration: A qualitative study of teachers and school principals. Scandinavian Journal of Educational Research, 64(3), 425-439. https://doi.org/10.1080/00313831.2019.1570548

[17] Holmes, W. T., \& Young, S. (2018). Culturally sustaining instructional leadership: Perspectives from Native American public school principals in Montana and Wyoming. Journal of Educational Leadership, Policy and Practice, 33(2), 17. https://doi.org/10.21307/jelpp-2018-010

[18] Smith-Millman, M. K., \& Flaspohler, P. D. (2019). School-Based Suicide Prevention Laws in Action: A Nationwide Investigation of Principals' Knowledge of and Adherence to State School-Based Suicide Prevention Laws. School Mental Health, 11(2), 321-334. https://doi.org/10.10 07/s12310-018-9287-y

[19] Reid, D. B. (2018). Making Sense of Teacher Evaluation Policies and Systems Based on Principals' Experience. Leadership and Policy in Schools, 1-15. https://doi.org/10.1 080/15700763.2018.1554158

[20] Fitzgerald, J., \& Radford, J. (2020). Leadership for inclusive special education: a qualitative exploration of SENCOs' and principals' Experiences in secondary schools in Ireland. International Journal of Inclusive Education, 1-16. https://doi.org/10.1080/13603116.2020.1760365

[21] Reber, R. (2019). Making school meaningful: Linking psychology of education to meaning in life. Educational Review, 71(4), 445-465. https://doi.org/10.1080/00131911. 2018.1428177

[22] Reid, D. B. (2019). What information do principals consider when evaluating teachers?. School Leadership \& Management, 1-21. Epub ahead of print. https://doi.org/10.1080/13632434.2019.1576167

[23] Abio, G. A., \& Stoyanova, A. (2018). Applying Active Learning Methods in Higher Education. Revista d'Innovació i Recerca en Educació, 11(2), 65-69. https://doi.org/10.1344/reire2018.11.220778

[24] Martinez, J. A. (2020). A Call for Help?: How Public School Principals' Subjective Report of Institutional Weakness Relates to Disciplinary Incidents. Journal of School Violence, 1-10. https://doi.org/10.1080/15388220.2020.172 9780

[25] Jeong, J. S., González-Gómez, D., Gallego-Picó, A., \& Bravo, J. C. (2019). Effects of active learning methodologies on the students' emotions, self-efficacy beliefs and learning outcomes in a science distance learning course. JOTSE: Journal of Technology and Science Education, 9(2), 217-227. https://doi.org/10.3926/jotse.530

[26] Shekhar, P., Prince, M., Finelli, C., Demonbrun, M., \&
Waters, C. (2019). Integrating quantitative and qualitative research methods to examine student resistance to active learning. European Journal of Engineering Education, 44(1), 6-18. https://doi.org/10.1080/03043797.2018.1438988

[27] Reid, D. B. (2020b). Teachers' perceptions of how principals use new teacher evaluation systems. Teachers and Teaching, 26(1), 129-144.https://doi.org/10.1080/13540602.2020.174 0199

[28] Cheng, L., Ritzhaupt, A. D., \& Antonenko, P. (2019). Effects of the flipped classroom instructional strategy on students' learning outcomes: A meta-analysis. Educational Technology Research and Development, 67(4), 793-824. https://doi.org/10.1007/s11423-018-9633-7

[29] Moliner, L., \& Alegre, F. (2020). Attitudes, beliefs and knowledge of mathematics teachers regarding peer tutoring. European Journal of Teacher Education, 1-20. Epub ahead of print. https://doi.org/10.1080/02619768.2020.1803271

[30] Miravet, L. M., García, O. M., \& Ciges, A. S. (2013). Enseñar y aprender Biología y Geología a través de la tutoría entre iguales [Teaching and learning Biology and Geology through peer tutoring]. Enseñanza de las ciencias: revista de investigación y experiencias didácticas, 31 (3), 189-206. https://doi.org/10.5565/rev/ec/v31n3.826

[31] Gaias, L. M., Johnson, S. L., Bottiani, J. H., Debnam, K. J., \& Bradshaw, C. P. (2019). Examining teachers' classroom management profiles: Incorporating a focus on culturally responsive practice. Journal of School Psychology, 76, 124-139. https://doi.org/10.1016/j.jsp.2019.07.017

[32] Stöhr, C., Demazière, C., \& Adawi, T. (2020). The polarizing effect of the online flipped classroom. Computers \& Education, 147, 103789. https://doi.org/10.1016/j.compe du.2019.103789

[33] Leithwood, K., \& Jantzi, D. (1990). Transformational leadership: How principals can help reform school cultures. School effectiveness and school improvement, 1(4), 249-280. https://doi.org/10.1080/0924345900010402

[34] Chesler, M., Schmuck, R., \& Lippitt, R. (1963). The principal's role in facilitating innovation. Theory into practice, 2(5), 269-277. https://doi.org/10.1080/004058463 09541875

[35] Ogawa, R. T., \& Weaver Hart, A. N. N. (1985). The effect of principals on the instructional performance of schools. Journal of Educational Administration, 23(1), 59-72. https://doi.org/10.1108/eb009901

[36] McEvoy, B. (1987). Everyday Acts: How Principals Influence Development of Their Staffs. Educational Leadership, 44(5), 73-77.

[37] Mahan, J. M. (1970). The teacher's view of the principal's role in innovation. The Elementary School Journal, 70(7), 359-365.

[38] Conley, S. C. (1989). " Who's on First?" School Reform, Teacher Participation, and the Decision-Making Process. Education and Urban Society, 21(4), 366-379. https://doi.org/10.1177/0013124589021004002

[39] Tingle, E., Corrales, A., \& Peters, M. L. (2019). Leadership development programs: Investing in school principals. Educational Studies, 45(1), 1-16. https://doi.org/10.1080/03 
055698.2017.1382332

[40] Cáceres, M. G. (2019). Social Factors Related to Leadership Skills and Educational Achievement of Primary School Principals. Revista d'Innovació i Recerca en Educació, 12(1), 1-16. https://doi.org/10.1344/reire2019.12.122122

[41] Quinn, D. M. (2002). The impact of principal leadership behaviors on instructional practice and student engagement. Journal of educational administration, 40(5), 447-467. https://doi.org/10.1108/09578230210440294

[42] Mitchell, C., \& Sackney, L. (2006). Building schools, building people: The school principal's role in leading a learning community. Journal of School Leadership, 16(5), 627-640. https://doi.org/10.1177/105268460601600512

[43] Mullen, C. A., \& Hutinger, J. L. (2008). The principal's role in fostering collaborative learning communities through faculty study group development. Theory into practice, 47(4), 276-285. https://doi.org/10.1080/0040584080232913 6

[44] Hallinger, P., Liu, S., \& Piyaman, P. (2019). Does principal leadership make a difference in teacher professional learning? A comparative study China and Thailand. Compare: A Journal of Comparative and International Education, 49(3), 341-357. https://doi.org/10.1080/03057925.2017.1407237

[45] Romanowski, M. H., Sadiq, H., Abu-Tineh, A. M., Ndoye, A., \& Aql, M. (2019). The skills and knowledge needed for principals in Qatar's independent schools: policy makers', principals' and teachers' perspectives. International Journal of Leadership in Education, 22(6), 749-773. https://doi.org/10.1080/13603124.2018.1508751

[46] Drescher, M., \& Edwards, R. C. (2019). A systematic review of transparency in the methods of expert knowledge use. Journal of applied ecology, 56(2), 436-449. https://doi.org/10.1111/1365-2664.13275

[47] Singh, R., Verma, H. K., \& Sharma, P. (2016). Efficient Estimators of Finite Population Mean using Predictive Estimation in Simple Random Sampling. Journal of Statistics, 23(1), 1-11.

[48] Cornesse C., \& Bosnjak, M. (2018) Is there an association between survey characteristics and representativeness? A meta-analysis. Survey Research Methods 12(1): 1-13. https://doi.org/10.18148/srm/2018.v12i1.7205

[49] Onwuegbuzie, A. J., Bustamante, R. M., \& Nelson, J. A. (2010). Mixed research as a tool for developing quantitative instruments. Journal of mixed methods research, 4(1), 56-78. https://doi.org/10.1177/1558689809355805

[50] Krosnick, J. A., \& Fabrigar, L. R. (1997). Designing rating scales for effective measurement in surveys. Survey measurement and process quality, 141-164. https://doi.org/10.1002/9781118490013.ch6

[51] Landeta, J. (2006). Current validity of the Delphi method in social sciences. Technological forecasting and social change, 73(5), 467-482.https://doi.org/10.1016/j.techfore.2005.09.0 02

[52] Dillman, D. A. (1991). The design and administration of mail surveys. Annual review of sociology, 17(1), 225-249. https://doi.org/10.1146/annurev.so.17.080191.001301

[53] Brownstein, N. C., Louis, T. A., O’Hagan, A., \& Pendergast,
J. (2019). The Role of Expert Judgment in Statistical Inference and Evidence-Based Decision-Making. The American Statistician, 73(1), 56-68.https://doi.org/10.1080/ 00031305.2018.1529623

[54] Cobanoglu, C., Moreo, P. J., \& Warde, B. (2001). A comparison of mail, fax and web-based survey methods. International journal of market research, 43(4), 1-15. https://doi.org/10.1177/147078530104300401

[55] Wilson, F. R., Pan, W., \& Schumsky, D. A. (2012). Recalculation of the critical values for Lawshe's content validity ratio. Measurement and evaluation in counseling and development, 45(3), 197-210.

https://doi.org/10.1177/0748175612440286

[56] Ayre, C., \& Scally, A. J. (2014). Critical values for Lawshe's content validity ratio: revisiting the original methods of calculation. Measurement and Evaluation in Counseling and Development, 47(1), 79-86. https://doi.org/10.1177/074817 5613513808

[57] Banerjee, M., Capozzoli, M., McSweeney, L., \& Sinha, D. (1999). Beyond kappa: A review of interrater agreement measures. Canadian journal of statistics, 27(1), 3-23. https://doi.org/10.2307/3315487

[58] Tinsley, H. E., \& Weiss, D. J. (1975). Interrater reliability and agreement of subjective judgments. Journal of Counseling Psychology, 22(4), 358.https://doi.org/10.1037/ h0076640

[59] Carden, S., Camper, T., \& Holtzman, N. (2019). Cronbach's Alpha under Insufficient Effort Responding: An Analytic Approach. Stats, 2(1), 1-14. https://doi.org/10.3390/stats20 10001

[60] Jöreskog, K. G., Olsson, U. H., \& Wallentin, F. Y. (2016). Multivariate analysis with LISREL. Basel, Switzerland: Springer. https://doi.org/10.1007/978-3-319-33153-9

[61] Osborne, J. W. (2015). What is rotating in exploratory factor analysis. Practical assessment, research \& evaluation, 20(2), $1-7$.

[62] Schreiber, J. B., Nora, A., Stage, F. K., Barlow, E. A., \& King, J. (2006). Reporting structural equation modeling and confirmatory factor analysis results: A review. The Journal of educational research, 99(6), 323-338. https://doi.org/10.3 200/JOER.99.6.323-338

[63] Hu, L. T., \& Bentler, P. M. (1999). Cutoff criteria for fit indexes in covariance structure analysis: Conventional criteria versus new alternatives. Structural equation modeling: a multidisciplinary journal, 6(1), 1-55. https://doi.org/10.1080/10705519909540118

[64] Delacre, M., Lakens, D., \& Leys, C. (2017). Why psychologists should by default use Welch's t-test instead of Student's t-test. International Review of Social Psychology, 30(1), 92-101. https://doi.org/10.5334/irsp.82

[65] Blanca, M., Alarcón, R., Arnau, J., Bono, R., \& Bendayan, R. (2017). Non-normal data: Is ANOVA still a valid option?. Psicothema, 29(4), 552-557. https://doi.org/10.7334/psicoth ema2016.383

[66] AlFallay, I. S. (2018). Test specifications and blueprints: reality and expectations. International journal of instruction, 11(1), 195-210. https://doi.org/10.12973/iji.2018.11114a 
[67] Mao, G. (2020). On high-dimensional tests for mutual independence based on Pearson's correlation coefficient. Communications in Statistics-Theory and Methods, 49(14), 3572-3584.

https://doi.org/10.1080/03610926.2019.1593459

[68] Walker, D. A. (2017). JMASM 48: The Pearson Product-Moment Correlation Coefficient and Adjustment Indices: The Fisher Approximate Unbiased Estimator and the Olkin-Pratt Adjustment (SPSS). Journal of Modern Applied Statistical Methods, 16(2), 540-546. https://doi.org/10.22237/jmasm/1509496140

[69] Hayes AF (2017) Introduction to mediation, moderation, and conditional process analysis: a regression-based approach. New York, NY: Guilford Publications.

[70] Bolívar, A., \& Moreno, J. M. (2006). Between transaction and transformation: The role of school principals as education leaders in Spain. Journal of Educational Change, 7(1), 19-31. https://doi.org/10.1007/s10833-006-0010-7

[71] Bolívar-Botía, A., \& Bolívar-Ruano, R. (2011). Schools principals in Spain: From manager to leader. International Journal of Education, 3(1), 1-18. https://doi.org/10.5296/ije. v3i1.463

[72] Ritacco, M. J., \& Bolivar, A. (2019). A dual and discontinuous professional identity: school principals in Spain. International Journal of Educational Management, 33(5), 806-827. https://doi.org/10.1108/IJEM-11-2016-0235

[73] Llorent-Bedmar, V., Cobano-Delgado, V., \& Navarro-Granados, M. (2019). School leadership in disadvantaged contexts in Spain: Obstacles and improvements. Educational Management Administration \& Leadership, 47(1), 147-164. https://doi.org/10.1177/174114 3217728084

[74] Berger, E., Reupert, A., \& Hasking, P. (2015). Pre-service and in-service teachers' knowledge, attitudes and confidence towards self-injury among pupils. Journal of Education for Teaching, 41(1), 37-51. https://doi.org/10.1080/02607476.2 014.992633

[75] Swanson, K., \& Gettinger, M. (2016). Teachers' knowledge, attitudes, and supportive behaviors toward LGBT students: Relationship to Gay-Straight Alliances, antibullying policy, and teacher training. Journal of LGBT youth, 13(4), 326-351. https://doi.org/10.1080/19361653.2016.1185765

[76] Kuyini, A. B., Desai, I., \& Sharma, U. (2018). Teachers' self-efficacy beliefs, attitudes and concerns about implementing inclusive education in Ghana. International Journal of Inclusive Education, 1-18. https://doi.org/10.1080/13603116.2018.1544298

[77] Henriksen, Ø. H., \& Aas, M. (2020). Enhancing system thinking-a superintendent and three principals reflecting with a critical friend. Educational Action Research, 1-16. https://doi.org/10.1080/09650792.2020.1724813

[78] Touloupis, T., \& Athanasiades, C. (2020). A comparison between primary school principals' and teachers' perceptions of students' online risk behaviours: the role of perceived self-efficacy. Cambridge Journal of Education, 1-18. https://doi.org/10.1080/0305764X.2020.1740170

[79] Barnett, C., \& Monda-Amaya, L. E. (1998). Principals' knowledge of and attitudes toward inclusion. Remedial and
Special Education, 19(3), 181-192. https://doi.org/10.1177/ 074193259801900306

[80] Watkins, S., Anthony, A. B., \& Beard, K. S. (2020). Principals' Sensemaking of Leading Under Accountability And Innovation Policies. Leadership and Policy in Schools, 1-21. https://doi.org/10.1080/15700763.2020.1734207

[81] Nadav, N., Benoliel, P., Shaked, H., \& Schechter, C. (2020). Exploring School Principals' Systems Thinking Activities. Leadership and Policy in Schools, 1-20. https://doi.org/10.1080/15700763.2020.1734208

[82] Araújo, H. C., Macedo, E., Santos, S. A., \& Doroftei, A. O. (2019). Tackling early school leaving: Principals' insights into Portuguese upper secondary schools. European Journal of Education, 54(1), 151-162. https://doi.org/10.1111/ejed.1 2328

[83] Turk, E. W., \& Wolfe, Z. M. (2019). Principal's Perceived Relationship Between Emotional Intelligence, Resilience, and Resonant Leadership Throughout Their Career. International Journal of Educational Leadership Preparation, 14(1), 147-169.

[84] Hayes, S. D., \& Irby, B. J. (2020). Challenges in preparing aspiring principals for instructional leadership: voices from the field. International Journal of Leadership in Education, 23(2), 131-151.https://doi.org/10.1080/13603124.2018.156 2102

[85] Nordholm, D., Arnqvist, A., \& Nihlfors, E. (2020). Principals' emotional identity-the Swedish case. School Leadership \& Management, 1-17. https://doi.org/10.1080/1 3632434.2020 .1716326

[86] Moswela, B., \& Kgosidialwa, K. (2019). Leadership and school success: Barriers to leadership in Botswana primary and secondary schools. Educational Management Administration \& Leadership, 47(3), 443-456. https://doi.org/10.1177/1741143217739355

[87] Prendergast, M., O'Meara, N., O'Hara, C., Harbison, L., \& Cantley, I. (2019). Bridging the primary to secondary school mathematics divide: Teachers' perspectives. Issues in Educational Research, 29(1), 243-260. Available in: https://www.iier.org.au/iier29/prendergast-abs.html

[88] Sun, A. Q., \& Xin, J. F. (2020). School principals' opinions about special education services. Preventing School Failure: Alternative Education for Children and Youth, 64(2), 106-115. https://doi.org/10.1080/1045988X.2019.1681354

[89] Bergmark, U., \& Hansson, K. (2020). How Teachers and Principals Enact the Policy of Building Education in Sweden on a Scientific Foundation and Proven Experience: Challenges and Opportunities. Scandinavian Journal of Educational Research, 1-20. https://doi.org/10.1080/003138 31.2020 .1713883

[90] Thody, A., Papanaoum, Z., Johansson, O., \& Pashiardis, P. (2007). School principal preparation in Europe. International journal of educational management, 21(1), 37-53. https://doi.org/10.1108/09513540710716812

[91] Lazenby, S., McCulla, N., \& Marks, W. (2020). The further professional development of experienced principals. International Journal of Leadership in Education, 1-15. https://doi.org/10.1080/13603124.2020.1716999

[92] Coronel, J. M., Moreno, E., \& Carrasco, M. J. (2010). 
Beyond obstacles and problems: women principals in Spain leading change in their schools. International journal of leadership in education, 13(2), 141-162. https://doi.org/10.1080/13603120903144442

[93] Sebastian, J., \& Moon, J. M. (2017). Gender Differences in Participatory Leadership: An Examination of Principals' Time Spent Working with Others. International Journal of Education Policy and Leadership, 12(8), 1-16. https://doi.org/10.22230/ijepl.2017v12n8a792

[94] Lorentzen, M. (2020). Principals' positioning of teacher specialists: between sensitivity, coaching, and dedication. International Journal of Leadership in Education, 1-19. https://doi.org/10.1080/13603124.2020.1737240

[95] Vestal, B., \& Torres, M. (2016). A Study of Preferred Conflict-Management Behaviors among Small-School Principals: Effects of Gender and Experience. Education Leadership Review, 17(2), 16-35.

[96] Randall, D. L., \& West, R. E. (2020). Who cares about open badges? An examination of principals' perceptions of the usefulness of teacher open badges in the United States. Open Learning: The Journal of Open, Distance and e-Learning, 1-19. https://doi.org/10.1080/02680513.2020.1752166

[97] Hauseman, C. (2020). Strategies secondary school principals use to manage their emotions. Leadership and Policy in Schools, 1-20. https://doi.org/10.1080/15700763.2020.1734 211

[98] Mancebón, M. J., \& Muñiz, M. A. (2008). Private versus public high schools in Spain: Disentangling managerial and programme efficiencies. Journal of the operational Research Society, 59(7), 892-901. https://doi.org/10.1057/palgrave.jo rs. 2602427

[99] Cordero, J. M., Prior, D., \& Simancas, R. (2016). A comparison of public and private schools in Spain using robust nonparametric frontier methods. Central European Journal of Operations Research, 24(3), 659-680. https://doi.org/10.1007/s10100-014-0376-1

[100] Goddard, R. D., Bailes, L. P., \& Kim, M. (2020). Principal Efficacy Beliefs for Instructional Leadership and their Relation to Teachers' Sense of Collective Efficacy and Student Achievement. Leadership and Policy in Schools, 1-22. https://doi.org/10.1080/15700763.2019.1696369

[101] Dronkers, J., \& Avram, S. (2010). A cross-national analysis of the relations of school choice and effectiveness differences between private-dependent and public schools. Educational Research and Evaluation, 16(2), 151-175. https://doi.org/10.1080/13803611.2010.484977
[102] Ferrera, J. M. C., Cebada, E. C., Chaparro, F. P., \& González, D. S. (2011). Exploring educational efficiency divergences across Spanish regions in PISA 2006. Revista de economía aplicada, 19(57), 117-145. Available in: https://www.redalyc.org/pdf/969/96922243005.pdf

[103] Crespo-Cebada, E., Pedraja-Chaparro, F., \& Santín, D. (2014). Does school ownership matter? An unbiased efficiency comparison for regions of Spain. Journal of Productivity Analysis, 41(1), 153-172. https://doi.org/10.1 007/s11123-013-0338-y

[104] Shaked, H., \& Schechter, C. (2017). School principals as mediating agents in education reforms. School Leadership \& Management, 37(1-2), 19-37. https://doi.org/10.1080/13 632434.2016.1209182

[105] Reid, D. B. (2018). Making Sense of Teacher Evaluation Policies and Systems Based on Principals' Experience. Leadership and Policy in Schools, 1-15. https://doi.org/10.1080/15700763.2018.1554158

[106] Aas, M., Vennebo, K. F., \& Halvorsen, K. A. (2020). Benchlearning-an action research program for transforming leadership and school practices. Educational action research, 28(2), 210-226. https://doi.org/10.1080/09650792.2019.15 66084

[107] Bauer, S. C., \& Silver, L. (2018). The impact of job isolation on new principals' sense of efficacy, job satisfaction, burnout and persistence. Journal of Educational Administration, 56(3), 315-331. https://doi.org/10.1108/JEA-07-2017-0078

[108] Taber, K. S. (2018). The use of Cronbach's alpha when developing and reporting research instruments in science education. Research in Science Education, 48(6), 1273-1296. https://doi.org/10.1007/s11165-016-9602-2

[109] Li, C. H. (2016). Confirmatory factor analysis with ordinal data: Comparing robust maximum likelihood and diagonally weighted least squares. Behavior research methods, 48(3), 936-949. https://doi.org/10.3758/s13428-0 15-0619-7

[110] Ermis-Demirtas, H. (2018). Establishing content-related validity evidence for assessments in counseling: Application of a sequential mixed-method approach. International Journal for the Advancement of Counselling, 40(4), 387-397. https://doi.org/10.1007/s10447-018-9332-4

[111] McNeish, D. M., \& Stapleton, L. M. (2016). The effect of small sample size on two-level model estimates: A review and illustration. Educational Psychology Review, 28(2), 295-314. https://doi.org/10.1007/s10648-014-9287-x 